\title{
The future of EU-Russia energy relations in the context of decarbonisation
}

\author{
Dr Olga Khrushcheva and Dr Tomas Maltby
}

*Pre-print version

Final version, published in Geopolitics:

http://www.tandfonline.com/doi/full/10.1080/14650045.2016.1188081

\begin{abstract}
In 2013, there was a joint commitment to "long term strategic EU-Russia energy cooperation". ${ }^{1}$ Whilst centred on oil and gas, it is noted that "the importance of renewables for EU-Russia energy relations should grow too", ${ }^{2}$ and that for energy efficiency, "cooperation potential is immense and could [...] contribute to the objective of a Pan-European energy area". ${ }^{3}$ Given this shared objective, this article analyses EU and Russian energy decarbonisation policy objectives and considers the potential for a supplementary trade relationship based on renewable energy flows and decarbonisation related technology, as well as the implications for existing energy trade. Despite declarative statements of mutual interest, shared objectives and cooperation in decarbonisation policy, there has been very limited cooperation by early 2016 . The EU has set ambitious plans to decarbonise its economy and energy sector by 2050 . However, in Russia energy policy is dominated by hydrocarbon exports, decarbonisation targets are modest, and there are major problems with their implementation. The drivers of EU and Russian energy policies are evaluated, and the argument advanced is that different understandings of energy security and types of energy governance provide major obstacles to decarbonisation cooperation and trade. However, it is argued that ideas about energy policy and security are contested and subject to change and there exists significant potential for mutual gain and cooperation in the longer term.
\end{abstract}

\section{Introduction}

The EU-Russia energy relationship, as energy trade in general, has traditionally been dominated by hydrocarbons; gas, oil and coal. The EU and Russia are positioned at opposite ends of the commodity chain, concerned by distinct though overlapping security priorities; security of energy demand and security of supply respectively, with both seeking a degree of stability of pricing. Transition to a low carbon economy incorporates an additional dimension to the established patterns of energy trade, raising the question of how much the process of decarbonisation will change relations between energy consumers and suppliers. This article focuses on the impact of strong EU decarbonisation objectives on EU-Russia energy relations, and explores the extent to which a supplementary energy relationship based on cooperation around decarbonisation objectives, including electricity trade and technology transfer has occurred and is likely. 
There exists a substantial interdependency between the EU and Russia; in 2014, Russia exported more than $70 \%$ of its oil and $90 \%$ of its gas to Europe ${ }^{4}$ and taxation of the oil and gas sector in the first half of 2015 Russia contributed 52\% of Russia's federal budget revenues, and $11 \%$ of GDP. ${ }^{5}$ In turn, the EU was dependent on Russia as its largest coal supplier, for $38 \%$ of its gas imports in 2013 and one third of its oil imports. ${ }^{6}$ Whilst conflict in Ukraine led to the suspension of some of formal forms of energy cooperation (for example the EU-Russia Energy Dialogue), a convergence of commercial interests between energy companies, Russia, the EU and its member states has left energy trade largely unaffected.

An analysis of the implications of climate change and decarbonisation policies on this relationship is under-considered in the literature. This is an important aspect of EU-Russia relations given the stated climate policies of each actor, commitments made at the Paris climate change conference in 2015 and the explicit objective of developing a decarbonisation related trade relationship. The EU has ambitious plans to achieve 80-95\% decarbonisation by 2050 primarily to combat climate change though also to manage energy import dependency. In this article, we consider the form and possibility of a 'decarbonised' energy relationship; the impact on both the existing EU-Russia hydrocarbon energy flows, as well as the potential for a supplementary 'decarbonised' trade of renewable energy and trade in technology.

We explore how divergent interests and drivers of energy policy in the EU and Russia, including conceptions of energy security and attitudes towards climate change, affect the commitment to decarbonisation objectives and their implementation. We find that Russian decarbonisation and climate change policy is markedly less ambitious than that of the EU and characterised by a failure to implement relatively modest policy objectives. The significance of the findings is supports for the central assertion by Kuzemko that energy policy is based not simply on material capabilities, but also understandings of energy; the importance of "ideational contestation and change" and "approaches to energy governance"7 in policymaking. Divergence in ideas and approaches to energy policy between the EU and Russia exists and is a factor in explaining the fact that explicit declarative shared objectives have not yet led to any significant cooperation on decarbonisation related to energy efficiency and renewables policy. Although material factors are important in structuring relations between the EU and Russia, the power of ideas in the policymaking and implementation process is found to be important. 
The relationship between power and ideas is here conceived to be one which considers the role for "alternative frameworks of ideas" to challenge dominant ideas and embedded institutions", particularly during periods of crisis. ${ }^{8}$

A collectively held understanding of environmental security is largely absent. However, a temporal analysis reveals that Russian energy policy is also subject to contestation and change. Kuzemko's work has also highlighted change and contestation of ideas within the EU. ${ }^{9}$ The originality of this contribution is in highlighting that whilst decarbonisation policies have not yet added significant new strand to the (hydrocarbon dominated) EU-Russia energy relationship there is some overlap of interests, and there is a limited coalition in Russia advocating policy change that would increase this overlap. There exists the potential for mutual interest in improving energy efficiency and related technology trade, and renewable energy trade too. Importantly, energy efficiency and renewables are relatively less politicised issues, and represent a potential basis for cooperation including the resumption of the suspended EURussia energy dialogue and work towards the stated mutual objectives.

The article is structured as follows: The first section outlines how the EU-Russia political and energy relationship has been conceptualised, and engages with work on the geopolitics and materially derived nature of the relationship, developing this to incorporate literature that considers the role for ideas and change. The article proceeds in section three and four to examine EU and then Russian energy and decarbonisation policy, including the decarbonisation objectives of both, and also evaluates the drivers of energy policy to assess the political will to meet stated objectives. Section five concludes with an assessment of the extent to which there is a convergence of decarbonisation objectives and the implications for EURussia energy relations.

\section{Conceptualising EU-Russia energy relations}

\section{Conflict: Geopolitics and conflicting identities}

This section evaluates the 'return' of geopolitics to the EU-Russia energy relations. Both history and geography structure EU-Russia energy relations, with Bridge one of many emphasising the interlinkage between the politics of energy security and geographies of supply and demand. ${ }^{10}$ There is an asymmetry ${ }^{11}$ or "spatial differential between these geographical realms", ${ }^{12}$ between exporter and importer. The EU's attempts to export its values and 
encourage greater liberalisation of Russian energy sector were unsuccessful, with the EU now introducing more explicitly geopolitical tools to increase security of supply. ${ }^{13}$ Carbon emission reduction strategies cannot replace hydrocarbons completely in the short or medium term, therefore energy consumers such as the EU will continue to depend on energy imports. ${ }^{14}$ However, the low carbon transition adds another dimension to the geopolitics of energy trade, as another commodity on the international energy market. ${ }^{15}$

For the Russian Government, energy is more than just a tradeable commodity; ${ }^{16}$ it is core to both economic development and to the restoration of 'great power' status in the international system. ${ }^{17}$ The Russian government explicitly frames energy policy not only in economic, but also in political and geopolitical terms, ${ }^{18}$ and it has been claimed internally that the development of the energy sector is "a way to strengthen Russia's position in the world". ${ }^{19}$ Such a position is not exclusive to Russia, but applies to many other energy producing states. High energy prices in the 2000s allowed many energy producing states (Russia, Venezuela, Sudan, Nigeria) to accumulate hard currency reserves, ${ }^{20}$ and increase state-control of energy sectors. ${ }^{21}$ Increased state control over the energy sector has resulted in barriers for foreign investment, has undermined decarbonisation policies, and clashes with liberalisation of energy trade promoted by Western energy consumers. Since 2000 Russian leaders have seen revenues from the energy sales as a way to reconstruct country's economic and political power. ${ }^{22}$ The 2009 Russian Security Strategy emphasises that "one of the main long-term directions of national security in the economic sphere is energy security". ${ }^{23}$ Russian power and influence in international politics is derived significantly from energy trade, Russia as an "energy superpower", which also affects how Russian energy policy is interpreted externally. ${ }^{24}$

On the one hand it has been argued that the relationship between the EU and Russia is, and will be, one of 'peaceful coexistence', ${ }^{25}$ with WTO membership one example of how the two actors might be drawn into a more interdependent and cooperative relationship. However, a number of authors conceive the relationship as one between different actors - liberal and realist - which has driven 'strategic rivalry' rather than partnership, with Russia understood to be focused on independence and sovereignty, seeking great power status and the defence of national interest. ${ }^{26}$ This fits with Buzan's ${ }^{27}$ understanding of a wider neighbouring society that is based on survival and self-interest, and that of Grajauskas and Kasciunas, who state that "ideological differences inevitably translate into the lack of trust and exacerbation of geopolitical tensions in the shared neighbourhood". ${ }^{28}$ Similarly, Haukkala argues that there is a stark distinction between the identities of Russia and the EU, between a sovereign and post-sovereign actor, 
resulting in "a clash". ${ }^{29}$ Energy policy priority differences are linked to the opposing roles of energy producer and consumer; however, it is argued that divergent identities exacerbate these differences and provide an obstacle to cooperation.

The postmodern nature of the EU has been echoed in its discourse related to Russia, and cited as a reason for difficulties in the relationship. ${ }^{30}$ Whilst energy producing states were moving towards re-nationalisation of energy production, the EU opted for greater liberalisation of the energy sector. This creates 'dysfunctional' energy relations between energy consumers and energy producers in terms of common legislation and policy between the two. ${ }^{31}$ The EU's role in and conception of international relations is a multilateral and legalistic one in which interdependence is key. ${ }^{32}$ Attempts have been made to export EU policies and norms to third countries, including Russia, in the energy sector. ${ }^{33}$ Examples include the Energy Charter Treaty (ECT), designed to provide a legal basis for a multilateral framework for energy cooperation, ${ }^{34}$ and the Energy Community initiatives. This has been based on the external projection of internal policy, in which three Energy Packages since the 1990s have set out to reform national energy markets and create interconnected, integrated and competitive markets. ${ }^{35}$ Energy policies and norms are a key function of the EU's 'soft', normative power, 'its ability to shape conceptions of "normal" in international relations" 36 and to export EU energy legislation and policy. However, this has not been successful with regard to Russia which, in 2009, stopped the provisional application of the ECT and demanded an equal partnership rather than one based on Russia following EU policies. ${ }^{37}$

EU-Russia energy relations have become increasingly politicised since the mid-2000s. ${ }^{38}$ This has occurred in response to rising prices ${ }^{39}$ but also the perception by the EU that Russia has used its energy resources "as a means of asserting its power", ${ }^{40}$ with disruptions of Russian gas supplies and selective pricing a result of geopolitically driven Russian foreign and energy policy, and resource nationalism within Russia (as opposed to market liberal approaches to energy governance in the EU). Klinke questions the strict dichotomy of a postmodern EU and a modern geopolitical Russia; between an actor characterised by pooled sovereignty and the “disappearance of geopolitics' and one that is based on 'national identity and traditional geopolitics". ${ }^{41}$ Gower and Timmins are amongst those who point to "the gradual re-emergence of zero-sum calculations and geopolitical competition", ${ }^{42}$ applying to the EU as well as Russia. Similarly, Kuzemko has argued that "EU enlargement eastwards has also reinforced notions of sovereign action in energy as well as of Russia as "other""43 with "geopolitical notions" 
increasingly influencing EU energy policy ${ }^{44}$ in part due to changing constellations of actor preferences in an enlarged EU, but also as a result of the perceived failure of liberal market policies to deliver security of supplies. Goldthau and Sitter also point to the EU as a mostly liberal actor in a realist world, at times using external tools that are exceptions to liberal market rules, such as state intervention and diplomacy. ${ }^{45}$ EU enlargement has seen a number of newer member states advocating less reliance on Russian energy and more (geo)politically-orientated objectives. ${ }^{46}$ As an example, the EU's proposed gas pipeline projects are driven by political as well as commercial imperatives. ${ }^{47}$

\section{Cooperation: commonality of interests and the role of ideas}

The article recognises that a contribution to the literature on EU-Russia energy relations needs to acknowledge the presence of geopolitics and strategic rivalry. This is materially and historically conditioned and linked to different forms of energy governance. However, despite different identities and tensions in the energy trade, interdependence continues to characterise energy trade. We argue that a) commonality of interests can exist despite major preference divergence; and b) actor identities and interests are not fixed and as Kuzemko argues, but rather that ideas are powerful within energy policy-making. ${ }^{48}$

Despite the divergence of preferences and the presence of geopolitical rivalry, energy policy has not been primarily characterised by conflict. Among the divergent preferences noted above, there exists a significant stability of relations. For example, the EU-Russia Energy Dialogue was established in 2000, and a Roadmap to 2050 was agreed in 2013, which commits the parties to share long term objectives, reduce risk and identify common interests - of which trade related to decarbonisation is one. ${ }^{49}$ Whilst weakly institutionalised, with both Russia and the EU generally prioritising bilateral energy diplomacy, the Dialogue enabled the establishment of a gas forum for businesses and regulators, an early warning gas disruption mechanism and contributed towards the resolution of long-term supply contract disputes. ${ }^{50}$

The 2013 Roadmap acknowledged Russia's interest in security of demand, and the EU's in security of supply, yet highlights interdependence and that sharing information about strategies and long term plans is key. ${ }^{51}$ Whilst the Dialogue has been suspended since 2014 as a response to the conflict in Ukraine, there is a high degree of stability of relations in hydrocarbon trade and there has been no substantial transit disruption to Russian gas supplies between February 
2009 and April 2016. This continuity exists because of commercial imperatives, and the common interest of the EU, Russia and other actors in continued trade. Neither actor has a short term alternative to securing demand or supply.

As such, some commonality of interests is required to facilitate a new partnership of trade, expertise and finance related to energy decarbonisation. It is the purpose of this article to investigate whether this commonality exists, and considering the role of ideas, whether there has been change over time. The decarbonisation agenda of the EU-Russia energy dialogue is potentially promising as it less rooted in the asymmetry of a consumer-supplier, import-export relationship. As noted by Aalto, decarbonisation could serve to strengthen "the informational and institutional dimensions of the Russian-European relationship", ${ }^{52}$ but also the material basis of the relationship in terms of technology transfers and Renewable Energy Source (RES) flows. The 'Cooperation Pathway' of the Roadmap highlights mutually beneficial cooperation on decarbonisation policy, noting that this "is in the interest of both sides" and is a priority. ${ }^{53}$ The Roadmap also recognises Russia's "high" energy efficiency potential and "immense" renewable potential, and that "EU-Russia cooperation on renewables is currently underdeveloped". ${ }^{54}$ The International Energy Agency estimates a technical energy efficiency potential equivalent to a third of Russia's energy production. ${ }^{55}$

In terms of self-interest, the EU's motivation lies in the understanding that addressing global climate change requires the cooperation of other major economies,${ }^{56}$ and that, in terms of decarbonising its energy supply, there are synergies with Russia. Toke and Vezirgiannidou have highlighted how the EU's decarbonisation policy could be considered threatening to Russia in the long term, since security of demand would be undermined by the EU's steadily declining market for Russian hydrocarbon exports. ${ }^{57}$ However, in the short to medium term (at least until 2030), in the absence of significant progress in electricity storage technology, gas is considered to be important back-up capacity to intermittent renewable energy production, "which could be a strong basis for deeper EU/R[ussian] F[ederation] cooperation". ${ }^{58}$

If the decarbonisation element of the EU-Russia dialogue is to be more than empty rhetoric and ambitious objectives, the development of this partnership requires a degree of commonality in understandings of climate policy. This means commitment to policy making and implementation; the political will to develop renewable energy and increase energy efficiency, in both the EU and Russia. We investigate whether such a commonality of interests exists, 
driven by environmental security or economic concerns, and whether there has been change over time. In considering the EU and Russia, each has a distinct 'worldview' when it comes to energy, defined by Bouzarovski and Bassin as "bound up with national politics and cultural self-determination...[the] interdependence between energy and identity".59 Worldviews structure policy choices, in this case about the role of energy in society.

It is clear from a cursory examination of EU and Russian climate objectives that there is a considerable difference in understanding of environmental security and the importance of addressing climate change. We recognise the role of material interests and the spatially embedded energy relationship, and the logic of geopolitics that can arise because of different worldviews that are held. However, we assume that these worldviews are not fixed, but in a process of continual contestation; linked to material factors but in line with constructivist assumptions they are also a product of discourse, argumentation and persuasion, ${ }^{60}$ within the EU and Russia, and between these actors via, for example, the EU-Russia Energy Dialogue. These worldviews are conditioned by changing material factors and relative power capabilities - but also from a change in knowledge through learning, ${ }^{61}$ and from ideational contestation. Whilst there is inertia within this, as "actions to innovate will be met with counter-actions to resist change and hold intact the existing set of preconditions for practice", ${ }^{62}$ change does occur, through political and societal debate. ${ }^{63}$ Ideas structure policy practices, confer authority and legitimate policy choices, and are contested with alternative frameworks of ideas. ${ }^{64}$ Understandings of security - energy and environment - are context-dependent, and vary across time and space, in line with proponents of the securitization theory ${ }^{65}$ and through ideational contestation. Understandings of energy policy, and the structuring of policy choices, are subject to change.

Both material interests and ideas structure policy practices (such as type of energy governance) and choices (such as renewable energy policy support mechanisms). Key actors in Russia and the EU assign different meanings to energy and environmental security. In turn this affects the potential for the substantial institutionalisation of a relationship, a partnership beyond mere rhetoric and ambitious objectives found in institutions such as the 'EU-Russia dialogue'. Policies and trade (of renewable energy and energy efficiency technology) can be framed in different ways; as mutually (un)beneficial, as (un)important, as (un)threatening. Ideas here are integral, and this article investigates through analysis of policy objectives, policy 
implementation and policy drivers, whether understandings of energy particularly with regard to climate related policy overlap.

We can see in the analysis above that the two actors have been characterised as fitting within binaries: postmodern/modern; post sovereign/sovereign; security of demand/security of supply focused; geopolitically/market liberal or legal. However, neither actor adheres fully to these ideal types. As argued by Klinke, what characterises EU-Russia relations are "two competing modernities (as well as two different geopolitical logics)". ${ }^{66}$ Within these two competing logics, the energy relationship is not fixed and unchanging. Rather the interests and identities of both are a product of the material reality, of spatial and territorial differences, but also of dynamic contestation of ideas and evolving understandings of energy security, within and between the two actors.

The development of a hydrocarbon energy relationship supplemented by renewable energy (and technology) trade, is contingent on a sufficient convergence of interests and political will in implementing such policies in addition to the existing and less onerous non-binding commitment to such objectives. What is also required is a shared understanding of the benefits to be gained from cooperation. This means a shared commitment to decarbonisation policies even if the drivers of this commitment do not overlap completely and are based to different extents on economic, security or power concerns (including on the international stage). The research then attempts to identify the extent of commonality of decarbonisation agendas and the potential effect on existing, and potentially supplementary, energy trade relations.

\section{Methodology}

As the focus here is on decarbonisation policy, the mechanisms for change of policy are changing elites or constellations of elite actors (change from above), societal attitude (change from below), and change facilitated by institutions that provide fora for interaction, persuasion and communication. The development of policy is traced, along with an analysis of discourse, to gain an insight into the development of EU and particularly Russian policy positions and objectives, and the drivers of these. We map out both discourse and practice, as well as problem framing, policy objectives and implementation. Utilising a policy tracing methodology to examine the development of government policy with reference to primary policy and 
legislative documents permits an assessment of dominant ideas, and policy responses in both the EU and Russia.

As Herranz-Surralle has highlighted, it is important when considering (policy) practices to "distinguish[ing] analytically between the rules and their implementation or "enactment" order to explore gradual change. We examine the evolution of policy discourse and objectives, and then the implementation of these in terms of policy practices and the development of a legislative and regulatory framework. The linkage between energy, environmental, economic, and foreign policy objectives is also explored. The analysis here triangulates data from the academic literature, primary government documents and reference to 13 interviews with key actors in Russia and the EU. We examine three main research questions:

a) What are the dominant worldviews regarding energy policy in Russia and the EU? With regard to environmental security and more specifically climate change, what ideas do decisionmaking elites hold on climate change? Is this an issue that is considered to be happening, a problem and a priority?

b) How have these structured policy choices? What policy objectives have been set, and to what extent have these been implemented?

c) Has there been any change over time in understandings of energy security and climate policy choices? Does this indicate that trade and cooperation on decarbonisation technologies and energy trade will be a significant supplement to the existing hydrocarbon relationship?

\section{EU decarbonisation policy, drivers and implementation}

After the failure of a carbon tax proposal in the 1990s, the EU signed the Kyoto protocol as a bloc in 1997. This stimulated EU-level policies to reach the emissions reduction target ${ }^{68}$ and led to a more ambitious period of EU environmental energy policy-making, amidst warnings about the dangers of climate change. Important 'enabling factors' included a "dynamic of competitive leadership reinforcement" ${ }^{69}$ in which certain member states sought to demonstrate leadership, and the EU sought to project climate leadership internationally. The EU sought also to use climate policy to promote European political integration, and ideas of ecological modernisation and 'green growth' became more influential. ${ }^{70}$ It was also considered that "in the 2000s, climate change clearly became part of 'high politics' as it was established as a top agenda item for virtually every bilateral, regional and global encounter of world leaders". ${ }^{71}$ 
Yet, as will be argued, this applied only to a limited degree in Russia. The EU's 2001 nonbinding target for renewable electricity generation was followed with a Summit in late 2005 calling for renewed action on climate change and insecurity of supply. ${ }^{72}$ The 2007 Europe 2020 Strategy and legislation in 2009 set for the first time binding national targets for renewables, of $20 \%$ by 2020 . In October 2009 the EU's member states committed to reduce CO2 emissions by $80-95 \%$ by 2050 .

This legislation contributed to an increase in renewables in the energy mix from $8 \%$ in 2004 to $15 \%$ in $2013,{ }^{73}$ and has been followed by a binding target at the EU level of $27 \%$ for $2030 .{ }^{74}$ A non-binding energy efficiency target of a $20 \%$ reduction against projected use was set in 2009. The implementation of this has been broadly successful, with the target set to be achieved or missed by $1-2 \% .^{75}$ The target has been increased to $27 \%$ by $2030 .{ }^{76}$

Drivers of EU energy and renewable energy policy: commitment to environmental policy and leadership and synergies with energy security

The European Commission makes a link between climate change, environmental security, and energy security. Commission interviewees argued that security of supply and climate change were objectives which in the mid to late 2000s became "mutually reinforcing....increasing efficiency and reducing demand required for both", 77 and that the "link with climate change in energy policy is [considered] permanent" ${ }^{78}$ despite policy coordination issues. ${ }^{79}$ This link, of environmental security as part of energy security, is far less emphasised by Russia. The Commission has argued that, “in the long term, the Union's energy security is inseparable from and significantly fostered by its need to move to a competitive, low-carbon economy which reduces the use of imported fossil fuels". ${ }^{80}$ Climate change-related security risks were also prioritised to a greater extent in the 2008 version of the European Security Strategy, compared to the 2003 version. ${ }^{81}$

In December 2015, 195 countries adopted the long-term goal to limit global warming below $2{ }^{\circ} \mathrm{C}$. Prior to this the EU had committed to reduce CO2 emissions by $80-95 \%$ by $2050 .{ }^{82}$ The future of coal power generation is one of the challenges faced by the EU member states. Whilst still accounting for a quarter of all EU electricity production, being competitively priced and limiting import dependence for some of the member states, coal-generating capacity declined substantially (by 24GW) between 2010 and 2014 and as the most carbon intensive fuel is a 
priority for the EU to address. ${ }^{83}$ The EU Emission Trading Scheme (ETS) launched in 2005 is currently in its third phase, and attempts to create a carbon price that will gradually phase out coal and other fossil fuels by pricing in the external cost of pollution. A surplus of allowances in the ETS, largely due to the economic crisis has resulted in lower carbon prices, weakening the incentive to reduce emissions. ${ }^{84}$ It is too early to judge whether reforms will effectively counter this surplus and low carbon prices, though the EU is reducing the annual emissions cap, postponing the auctioning of allowances and bringing in a Market Stability Reserve in an attempt to address the surplus. The Industrial Emissions Directive also requires the most polluting coal power stations to be upgraded, or to close ${ }^{85}$ Limits on coal power generation are likely to lead to an increase in natural gas consumption and imports, including those from Russia.

Supply disruptions, decreasing domestic energy supplies, increasing competition for demand, and rising energy prices reinforced the view that ambitious renewable energy targets would reduce energy import dependency. ${ }^{86}$ These dynamics also meant that post-2000, "the nexus between mitigation and energy security emerged as a powerful facilitator of multilevel reinforcement", ${ }^{87}$ which led to the EU's renewable, emissions and energy efficiency targets and policies.

Baker has discussed a driver of decarbonisation policy, and that of leadership aspirations in environmental (energy) policy as 'ecological modernisation' - "environmental management compatible with the raison d'etre of the EU integration project...the construction of a neoliberal, free market economy in support of industrial competitiveness", ${ }^{88}$ combining economic growth with climate change mitigation. This has contributed towards the formulation and implementation of ambitious decarbonisation objectives. Baker argues that this commitment to sustainable development has been a key factor in the identity and actorness of the EU, ${ }^{89}$ part of what Manners described as the EU's normative power. ${ }^{90}$

Toke and Vezirgiannidou ${ }^{91}$ are more sceptical about whether energy security incorporates sustainability, and similarly, Skovgaard claims that the environmental energy policy in the EU in recent years has been characterised by a struggle between:

“[T]he 'green growth policy frame' [which] defines the relationship between climate policy and economic growth as synergetic and consequently frames ambitious climate policy as a logical response to the crisis [and the] 'trade-off policy frame' [which] 
defines the relationship in terms of a trade-off, and consequently frames the crisis as limiting the scope for climate policy". ${ }^{92}$

Within the EU, the consensus regarding the norm of ecological modernisation is fraying somewhat. For example, Member States in Central Eastern Europe (CEE) have generally been less enthusiastic about ambitious decarbonisation targets. ${ }^{93}$ A higher priority has been security of supply and the preference to pursue supply diversification strategies. As Kuzemko notes, there is an "increasingly contested internal ideational landscape" 94 informing climate and energy policy making in the EU. Decarbonisation has been associated with economic and consumer losses, and has been associated with reducing energy import dependence to only a limited extent. ${ }^{95} \mathrm{CEE}$ states have generally demanded, and received, concessions leading to less onerous targets and further financial assistance for their energy transition. ${ }^{96}$ Economic arguments have also been increasingly influential in terms of constraining EU climate policy objectives, including those related to energy efficiency and renewables. ${ }^{97}$

This struggle has become more apparent since 2009. In March 2010, the Council requested an impact assessment of moving to a $30 \%$ cut in emissions by 2020 , but was opposed within the Commission by DG Energy, DG Industry, and outside by Poland, Italy and some other CEE states. ${ }^{98}$ In 2014, the European Parliament recommended 30-40-40 targets for renewables, energy efficiency and emissions respectively, the Commission counter proposed 27-30-40, and this was further reduced to $27-27-40$ by October. ${ }^{99}$ It is clear that ideological contestation exists both within and between EU institutions and member states. ${ }^{100}$ Whilst the EU is set to reach and exceed its 2020 targets, implementation problems remain, and a number of its member states face difficulties reaching their targets without substantial revision of their current plans. ${ }^{101}$ These member states may need to review their policies and engage more with the cooperation mechanisms proposed by the 2009 Renewables Directive; Article 9 allows Member States "to cooperate with one or more third countries on joint projects regarding the production of electricity from renewable energy". ${ }^{102}$

Directive 2009/28/EC names the Mediterranean Solar Plan (MSP) among "the projects of high European interest". ${ }^{103}$ However, one of the flagship projects, Desertec, a €400-billion project which aimed to provide $15 \%$ of the EU's energy by 2050 using solar energy from the Sahara, was abandoned in 2013 amongst concerns about the cost of the transmission infrastructure, in particular. ${ }^{104}$ Boute and Willems argue that electricity produced from biomass and onshore wind power in Russia's North-West is a better alternative, since Russia is already connected to 
the electricity markets of Finland, Estonia and Latvia. ${ }^{105}$ Joint projects generally remain at the potential rather than implemented stage, however.

Public consensus regarding the importance of the issue has also decreased. For example, in $2008,62 \%$ of the general public of the EU considered climate change the most serious global problem. ${ }^{106}$ This had dropped to $15 \%$ in 2015 , though $47 \%$ still thought it one of the most serious problems the world faced. ${ }^{107}$ Catalysts for decarbonisation policy in the EU have shifted from largely environmental security concerns in the early 2000s, to incorporating security of supply and price concerns since. In response to the financial crisis, decarbonisation targets have been scaled back somewhat; framed as a combination of climate change mitigation strategies, security of supply, and environmental security priorities. However, despite reduced political will for decarbonisation, EU targets remain ambitious in the global context. Vogler points to the discursive portrayal of decarbonisation objectives as "the ultimate 'win-win' or even 'winwin-win' set that aligns energy security with the security of the climate, ecological modernisation, and economic recovery". ${ }^{108}$ In 2009, Energy Commissioner Piebalgs argued that "climate change and energy security are two sides of the same coin. The same remedies must be applied to both problems". ${ }^{109}$ In setting decarbonisation targets for 2030, the 2014 EURussia-Ukraine tensions may have contributed towards an agreement despite the softening of environmental commitments, with the Climate Commissioner arguing in 2014 that the 2030 targets were "very good news for the climate...for investors...for Europe's energy security and independence. Meaning not such good news for Putin". ${ }^{110}$ The EU has consistently presented itself as a leader on climate change. ${ }^{111}$

\section{Russian decarbonisation policy, drivers and implementation}

Russia's commitment to climate policies in 2015 is one that remains characterised by "compliance without implementation", ${ }^{112}$ which Nikitina had noted in 2001. In the 1990s, Russian greenhouse emissions decreased by one third due to the economic recession. ${ }^{113}$ However, further progress has been limited. Despite the key strategic documents adopted in the 2000s, acknowledging the necessity for greater integration of RES and improving energy efficiency, the regulatory and legal framework was underdeveloped, and state funding to decarbonisation projects limited - yet this does not capture the evolution of policy objectives, implementation and contestation. 


\section{Renewables}

The 2003 Energy Strategy recommended increased investment in renewables, particularly biomass, with the objective of more than doubling 2000 production by 2020 (from $0.5 \%$ to $1 \%$ of total energy consumption). ${ }^{114}$ In October 2004, the State Duma ratified the Kyoto Protocol, ${ }^{115}$ and in March 2005, the Russian government developed the related National Action Plan, ${ }^{116}$ setting a target of increasing renewable energy production by two-to-three times by 2008. However, the legislative base remained largely underdeveloped. Only in 2008 did the Russian government adopt Decree N 426 setting the rules for the qualification process for renewable energy generating installations, ${ }^{117}$ but without a coherent implementation mechanism, and the 2008 target was missed.

The 2009 Energy Strategy paid more attention to renewables than its 2003 predecessor, ${ }^{118}$ setting an ambitious target of increasing the share of RES in the Russian energy mix from $0.5 \%$ in 2009 to $4.5 \%$ by $2020 .{ }^{119}$ Government Decree N 1-r set interim targets of $1.5 \%$ for 2010 , and $2.5 \%$ for $2015 .{ }^{120}$ Yet both the 2003 and 2009 Energy Strategies were considered to offer more "a guideline than a regulation", ${ }^{121}$ without clear mechanisms of support to drive investment of RES and energy efficiency, or penalties for non-compliance. ${ }^{122}$ Furthermore, a Federal Law regulating production of renewable energy does not exist in Russia. In particular, energy companies such as Gazprom do not consider development of renewable energy as their immediate priority. ${ }^{123}$

The share of RES in Russia increased from $0.5 \%$ in 2000 to $1 \%$ in $2010,{ }^{124}$ but in doing so missed the interim 2010 target of 1.5\%. ${ }^{125}$ By comparison, in the EU this figure had reached $12.5 \%$ in $2010,{ }^{126}$ exceeding the $12 \%$ target set in $2001 .{ }^{127}$ As a corrective, a 2011 Implementation Plan prescribed the development of the legislative framework necessary for improving energy efficiency and increasing the share of RES in the Russian energy mix. ${ }^{128}$ The share of RES in Russian energy consumption remained at approximately $1 \%$ in $2015,{ }^{129}$ and there has been a dramatic decrease in ambition; the draft energy strategy up to $2035^{130}$ proposed to replace the 'optimistic' $4.5 \% 2020$ RES target, with a more realistic target of $2.2 \% .{ }^{131}$ This is less than half the target set in $2009 .^{132}$

The most significant progress has occurred in geographically remote regions disconnected from the central grids (e.g. the Far East). In these regions, conventional electricity generation is 30 times more expensive than central parts of Russia, and renewable energy is seen as a more affordable alternative. ${ }^{133}$ For instance, $44 \%$ of the Tomsk region's budget is spent on energy 
resources. ${ }^{134}$ Economic motivation has stimulated the regional legislation process and, for example, the Republic of Yakutia has a regional law on renewable energy. ${ }^{135}$ As Aalto et al. argue it is "profit interests, as part of a wider business frame, [which] most centrally guide Russian [energy] actors". 136

However, even in these more remote areas progress remains insufficient, as there is considered to be both limited political will and a clash with economic interests of the established energy actors involved in sales of diesel fuel supplies to the region. ${ }^{137}$ The biggest wind farm in Russia with a capacity of 5.1MW is situated in the Kaliningrad Region. In 2012, this produced $6.8 \%$ of all electricity in the region. ${ }^{138}$ Most wind turbines were installed in the late 1990s, and now require major overhaul. In 2014, only 14 turbines out of 21 were in operation. ${ }^{139}$

State support is considered crucial for private investors, as the estimated return on the invested capital is up to 15 years, ${ }^{140}$ due to difficulties in the qualification process and connection to central electricity grids. ${ }^{141}$ An investment of $€ 7 b n$ is required to increase the share of RES in Russia to $2.5 \%$ by $2020 .{ }^{142}$ However, in terms of state funding the oil and gas sector has a priority. ${ }^{143}$ Incoherence of legislation makes it difficult for private sector to invest into development of renewable energy.

The existing legislation regulating installation of new RES generating facilities limits the scale of renewable energy production. To connect a RES generating facility to the energy grid, it should qualify and be selected through the tenders set by the authorities in the Federal Subjects. ${ }^{144}$ However, the qualification process is complex and includes a variety of different criteria, including the local content requirements. These require all RES installations to be at least partly produced or assembled in Russia. ${ }^{145}$ These 'localisation' targets increase year on year. In 2014 the local content requirement for wind power generating facilities was $35 \%{ }^{146}$ Foreign technology is then restricted, but foreign direct investment is too, as there is a reluctance to support Russian companies that lack a track record of production, ${ }^{147}$ and Western sanctions have reduced investment opportunities. ${ }^{148}$ Due to the complexity of qualification process it can be challenging for potential investors to fulfil all the requirements in time for the tender. $^{149}$

\section{Energy efficiency}

Due to aging infrastructure, Russia's energy intensity is considerably higher than that of the EU. ${ }^{150}$ The 2003 Energy Strategy indicated that this was an issue that should be addressed, with 
energy saved domestically used for export purposes. ${ }^{151}$ Furthermore, the Russian government recognised that improving energy efficiency is necessary for reducing $\mathrm{CO} 2$ emissions. ${ }^{152}$ Provisions on energy efficiency were included in all chapters of the 2009 Energy Strategy to $2030,{ }^{153}$ and tackling climate change was discussed prominently. ${ }^{154}$ In 2013, the Ministry of Economic Development stated that, "improving energy efficiency should be considered as an important precondition for future economic growth". 155

Compared to legislation on renewable energy, the regulatory and legal framework on energy efficiency is more developed. There are regional and municipal energy efficiency programmes. For example, in Perm $€ 115,000$ was allocated to energy efficiency project in 2010-2015 to implement energy efficiency policy objectives. ${ }^{156}$ With the 97 registered Joint Implementation projects it was clear that energy efficiency was also the priority, with only 6 projects focused on renewables - all of which concerned hydropower projects. ${ }^{157}$ A 2009 federal law defined the legal, economic and institutional mechanisms of support for improving energy efficiency. ${ }^{158}$ The law prescribed the further development of the legal and regulatory framework. Between 2009 and 2015, 12 laws were revised and amended. ${ }^{159}$ In 2009, penalties were introduced for non-compliance, ${ }^{160}$ however these are not considered strict enough, ${ }^{161}$ equivalent to only $€ 7,000-8,500 .^{162}$

The 2020 Energy Efficiency Programme mentions the success of reducing energy intensity by 5\% a year between 2000 and 2008. ${ }^{163}$ Yet whilst the energy efficiency of the public and housing sectors has demonstrated gradual improvement, industry and transport have failed to achieve substantial changes. The main decrease in energy intensity is a result of economic restructuring towards lighter industry rather than energy efficiency measures, ${ }^{164}$ and funding cuts are now planned by the government. In 2015 , the government planned to allocate $€ 174 \mathrm{~m}$ to energy efficiency projects, $€ 152 \mathrm{~m}$ in 2016 , and only $€ 113 \mathrm{~m}$ in $2017 .{ }^{165}$

\section{Drivers of Russian energy and renewable energy policy}

Russian decarbonisation objectives are then substantially less ambitious relative to the EU. This is not surprising, considering that fossil fuels have been the main focus of Russian energy policies since the early 1990s, ${ }^{166}$ and in May 2014 Putin confirmed that, "we will focus on the production of hydrocarbons and the development of nuclear generation". ${ }^{167}$

In contrast to the EU, climate change does not play a significant role in shaping Russian energy policy. In Russia, policy-making is executive dominated, ${ }^{168}$ and neither the executive nor the 
public have considered climate change particularly salient an issue. ${ }^{169}$ Where Russia has played a more active, or constructive, international role this coincided with a change (albeit qualified) at the executive level. As President, Medvedev considered it a foreign policy objective to contribute as a leader to debates at the Copenhagen climate conference in 2009 which was linked to the adoption of the Russian Climate Doctrine at that time. ${ }^{170}$ Modernisation and reform of the economy was considered important for domestic but also international reasons: reasserting great power status. An evolved strategic partnership with the EU (manifested as the EU-Russia Partnership for Modernisation), was also considered important, and included the objective of decarbonisation and tackling climate change. ${ }^{171}$

Medvedev argued in 2009 that Russia must "become a leading country measured by the efficiency of production, transportation and use of energy", ${ }^{172}$ and a year later linked climate policy, modernisation and national security. ${ }^{173}$ Whilst the President is not the only institutional veto player, climate and energy policy in Russia is concentrated in and around the executive, and the Russian Ministry of Energy which coordinates the EU-Russia Dialogue is considered to have relatively little influence over Russia's energy policy. ${ }^{174}$ With Putin's return to the Presidency in 2012, Medvedev's modernisation initiative faded, having achieved little, and a focus on climate change receded. Despite some explicit statements on the international stage to the contrary, ${ }^{175}$ it has been widely claimed that Putin has been sceptical about the importance of tackling climate change and influenced by those who doubt both the anthropogenic cause of climate change and also the extent of any negative influence on Russia. ${ }^{176}$ It is considered that there is a strong presence of 'climate-sceptic' group advising the policy-makers against committing to any greenhouse gas (GHG) reduction targets, ${ }^{177}$ fitting within a Skovgaard's description of a "trade-off policy frame"178 that emphasises the economic cost of commitment. ${ }^{179}$

Despite this, a small climate coalition of NGOs, academics, the media and actors within the Ministries of Economic Development and Foreign Affairs, the Presidential Administration, and UNFCCC negotiators are trying to "shift climate policies upwards on the political agenda". 180 For example, in June 2015 at the Saint Petersburg Economic Forum, the Environment Minister argued that by 2030 Russia could be losing 1-2\% GDP p.a. as a result of climate change. ${ }^{181}$ Russia committed in 2013 to limiting GHG emissions to $70-75 \%$ of 1990 s levels, ${ }^{182}$ and reaffirmed this in 2015 in the run up to the Paris UN Climate Change conference, albeit offering limited details on the implementation plans. ${ }^{183}$ The Russian government also plans to develop 
a system recording GHG emission volumes at major enterprises, ${ }^{184}$ and this may lead to the creation of the GHG emission-trading scheme. ${ }^{185}$ However, as argued by Korppoo et al., environmental concerns are officially supported internationally by Russian actors, “"mirror[ing]' the rhetoric of the negotiation partners in order to promote some other interests, especially those related to foreign policy, national image or economic benefits" 186 but "are almost completely absent as a supporting argument in the domestic debate". ${ }^{187}$ There is a lack of an environment-related policy driver. It is for this reason that it is important to assess policy implementation and evolution as well as documents designed at least in part to satisfy and impress an international audience.

Public opinion polls demonstrate a low level of awareness and concern of the potential negative consequences of the climate change, though some change. The number of people surveyed who thought that climate change was a problem increasing from $20 \%$ in 2005 to $28 \%$ in $2010 .{ }^{188}$ However, in 2013 , only $9 \%$ of respondents admitted that they are trying to use energy more efficiently for environmental reasons. ${ }^{189}$ The issue receives low coverage in politics and the media. ${ }^{190}$ This is important as it has been argued that the media can act as a catalyst for public pressure on climate policy-making, ${ }^{191}$ with energy transitions requiring a broader debate if established institutions and discourses are to be challenged, ${ }^{192}$ a situation which was lacking in 2015 in Russia.

The economic motivation for energy saving could become more significant due to the weakening of the Russian economy in 2014-15, and the 2009 energy efficiency law, which did recommend raising awareness of the general public about energy efficiency and energy savings. ${ }^{193}$ Also, as part of WTO commitments and ongoing EU-Russia cooperation, Russia will need to increase domestic energy prices, as household prices are regulated and industrial prices partly regulated. ${ }^{194}$ This would also help renewable energy technology compete in the market. Since 2010 Russia has increased regulated gas prices, however they are still lower than European gas prices. ${ }^{195}$ In 2013, consumer energy prices increased by $10 \%$ as compared to 2012. ${ }^{196}$ According to the Ministry for Economic Development, prices would then increase by 4.5-8.5\% per year until 2017, ${ }^{197}$ yet in September 2015 they were frozen until $2016 .{ }^{198}$ Existing pricing policy limits the ability to use price signals to encourage consumers to use energy more efficiently, ${ }^{199}$ however energy price liberalisation is limited for "social and competitiveness reasons". 200 
To overcome the problems with development of new natural gas fields and to meet export obligations, Gazprom needs to invest up to $€ 18$ billion p.a. until $2030 .{ }^{201}$ However, it has been estimated that increasing its energy efficiency, Russia could save the equivalent of $240 \mathrm{bcm}$ of natural gas and the equivalent of 43 million tons of crude oil. ${ }^{202}$ Annual Russian domestic consumption increased by approximately one quarter from 1997 to $2012 .{ }^{203}$ Minimising domestic energy use through energy efficiency measures maximises export volumes, and the Russian Energy Strategy up to 2030 states that Russia can potentially save up to $40 \%$ of domestic energy consumption. ${ }^{204}$ Shifting a proportion of investment from hydrocarbons to energy efficiency and renewables then could be perceived as economically rational. Despite a lack of government support, Rosneft announced a 2014 plan for energy efficiency to spend $€ 1 \mathrm{bn}$ in 5 years, and Lukoil and $\mathrm{EN}+$ both established 'green' daughter companies, ECOENERGO and EuroSibEnergo respectively. ${ }^{205}$

However, a Russian non-governmental actor outlined the main obstacle to realising the potential for RES, the lack of confidence in state support for the sector, ${ }^{206}$ and this was confirmed by a representative of Gazprom. ${ }^{207}$ Security of demand for conventional Russian energy sources and economic interests drive Russian energy policy. However, we have identified points of ideational contestation. Within government, particularly under Medvedev's presidency, there was also increased focus on the issue. Whilst there remains a hegemonic discourse that reflects a worldview that understands energy policy as focused on prioritising competitiveness and security (of demand), there is a small but growing public concern with pursuing more energy efficient and renewable objectives, and an energy industry which recognises the opportunities but bemoans lack of political support. This remains a point of potential mutual interest, on which it is argued that Russia may be receptive to European ideas, expertise, and financing related renewables and energy efficiency. ${ }^{208}$

\section{Conclusion:}

In terms of policy discourse, joint statements within the EU-Russia energy dialogue discuss a shared understanding of the potential for strong mutual benefit in developing a decarbonised relationship predicated on the trade of renewable energy (technology and physical flows) and energy efficiency technology. However, the desired "partnership" and "strong basis for deeper EU/RF cooperation"209 remains ambitious and largely declarative. Whilst a convergence of commercial interests and infrastructural interlinkages sustain gas trade despite poor political 
relations, there is little similar convergence of commercial-economic interests in relation to decarbonisation. Our analysis identified the following three problems related to divergent values: External energy policy strategy; types of energy governance systems and; understandings of energy security.

\section{1) External energy policy strategy}

Russia has resisted attempts by the EU to export its liberal market rules, for example with the ECT. Whilst Russia has long explicitly linked energy policy to foreign policy, this is also increasingly a characteristic of EU external energy policy in part as a result of this failure. As argued by authors such as Goldthau and Sitter, Gower and Timmins, Klinke, and Kuzemko 210 the monolithic dichotomy of a modern EU and postmodern Russia is flawed. The diversification of energy suppliers is now considered an EU priority, with political and financial support offered to realise projects that would not otherwise be commercially viable. The Ukrainian crisis led to sanctions since 2014 which limited the access of some major Russian energy access to European energy markets, ${ }^{211}$ and the EU-Russia Energy Dialogue was suspended. These problems limit the ability of the EU to use its normative power to export its values to Russia, and the EU explicitly discusses diversification away from Russia, increasing bargaining leverage in negotiations and bringing Russian energy companies into compliance with EU legislation.

\section{2) Types of energy governance}

The EU has to a large extent, until recently, relied on the market to deliver security of energy supplies. By contrast in Russia, particularly in the gas sector, there is more state intervention. Whilst many major international energy companies continue to invest, a series of events have increased risk and reduced opportunities, and smaller and medium-sized actors have been discouraged from investing in Russia. ${ }^{212}$ Partial expropriations and raids on international energy companies since $2006^{213}$ have been combined with broader concerns relating to the rule of law, inconsistency of Russian legislation, and 'localisation' targets which undermine foreign investment in renewable energy projects. EU investors perceive Russia as a higher risk country as a result, and Russia continues to prioritise the development of its domestic industry. ${ }^{214}$ 
3) Understandings of energy security. Prioritisation of environmental security varies significantly. This has had a substantial effect on policy-making and objective setting, and also on implementation. Particularly in Russia, objectives to date are unambitious, inconsistent and poorly implemented. There is negligible institutionalisation of the non-hydrocarbon energy relationship in terms of joint projects. Most of what was trialled was short term in nature and related to the Kyoto Protocol, which is no longer applied by Russia. Cooperation is limited to small-scale projects, such as exports of electricity to Finland from hydropower stations in Russia. The central role of the hydrocarbon trade for ensuring long-term economic growth has resulted in insufficient political will to develop, maintain and implement decarbonisation objectives. Commitment to climate policy in Russia has varied slightly, but generally has been low. The priority is security of demand for energy exports. In contrast, environmental security concerns remain a priority in the EU, despite concerns regarding economic costs of decarbonisation and the link between security of supply and climate policy, which decreases demand for imported energy.

These differences provide a significant obstacle to cooperation on decarbonisation objectives. However, the argument which has been advanced is that ideas about energy policy and security are contested and subject to change and there exists significant potential for mutual gain and cooperation in the longer term, particularly in an area less politicised than other aspects of the EU-Russia (energy) relationship. There is little evidence yet of collectively held norms related to the relative importance of the environmental dimension of energy security, and insufficient recognition of the economic potential of decarbonisation policies in Russia. However, we assume understandings of energy security are dynamic and have identified change in EU and Russian energy policy with regard to decarbonisation. Though modest this supports Kuzemko's explanation of the role of ideational contestation in the formulation of policy. Whilst these have had limited influence to date our empirical analysis has concluded that worldviews of energy are being challenged by alternative discourses in both the EU and Russia, with coalitions of actors opposed to the status quo. However, these have had limited influence to date.

The EU-Russian hydrocarbon relationship will continue to take precedence over cooperation on decarbonisation objectives. In the short to medium term Russia will remain a strategic provider of natural gas supplies to the EU, just as the EU will remain a strategic export market for Russian gas. The development of EU renewables will contribute to maintaining gas demand because of a growing reliance on gas as back-up capacity and also as a cleaner transition fuel than coal. Russia is likely to continue to meet a substantial if not increasing volume of this 
(even if the percentage of imports decreases). This will maintain, and could deepen, the EURussia gas relationship through to at least 2035. Even in the context of decarbonisation, natural gas will remain a core component of the EU-Russia energy relationship.

Decarbonisation policy practice may reflect cooperative discourse if it is 'successfully' framed either in economic and/or environmental terms in Russia. This may follow a change of elites/elite attitudes such as that found, to a limited extent, under Medvedev's presidency, a change of societal attitudes with concern about climate change continuing to increase from a low level, or a desire to be internationally influential or reacting to pressure from agreements made at international climate change negotiations. In Russia, as in the EU, it is evident that despite a dominant understanding of energy policy there is ideational contestation. There exists in the former a small coalition of actors in the media, academia, industry and government that promote greater commitment.

The existence of the EU-Russia energy dialogue allows, if resumed, for the mechanisms of argumentation and persuasion, an opportunity for the EU to exert soft power through knowledge based authority regarding renewable and energy efficiency policy. The issue is also one less politicised than fossil fuel energy trade, and is a good basis for developing this dialogue. Further research is required, in particular to assess the influence of alternative discourse and climate and energy policy-making in Russia, the implementation of post-2020 climate and energy policy in the EU, and the effect of any resumption of the EU-Russia energy dialogue. The EU and Russia will continue to have a significant energy relationship for decades to come, and this will be significant for broader foreign relations and also for the successful implementation of the Paris climate conference which requires the active participation of both actors.

\section{Acknowledgements}

The authors would like to thank Jack Sharples, Colin Flint and the anonymous reviewers for their constructive and comprehensive comments on earlier drafts of this article.

\section{List of interviews:}

Interview \#1: Permanent representative interview, 2010.

Interview \#2: Commission official, 2010. 
Interview \#3: Commission official, 2010.

Interview \#4: Commission official, 2010.

Interview \#5: Commission official, 2013.

Interview \#6: Gazprom representative, 2010.

Interview \#7: Moscow State Institute of International Relations (RES specialist) Non Governmental Actor (NGA), 2010.

Interview \#8: Commission official, 2010.

Interview \#9: EU-Russia Centre, 2010.

Interview \#10: National Energy Security Fund, 2010 [Russian NGO].

Interview \#11: Greenpeace Russia, 2015.

Interview \#12: NGA, 2015.

Interview \# 13 - IFC representative, 2015.

\section{NOTES}

${ }^{1}$ EU/RF Roadmap, 'Roadmap EU-Russia Energy Cooperation until 2050', European Commission and Russian Government, (March 2013), p. 4, https://ec.europa.eu/energy/sites/ener/files/documents/2013_03_eu_russia_roadmap_2050_si gned.pdf.

${ }^{2}$ Ibid, p. 21

${ }^{3}$ Ibid, p. 26.

4 EIA, 'Russia International energy data and analysis', 28 July 2015, http://www.eia.gov/beta/international/analysis_includes/countries_long/Russia/russia.pdf.

2 Expert Economic Group, 'Russian Government Federal Budget Execution', (2015) http://www.eeg.ru/pages/148.

3 European Commission, 'European Energy Security Strategy', (2014), p.2, http://ec.europa.eu/energy/doc/20140528_energy_security_communication.pdf

${ }^{7}$ C. Kuzemko, 'Ideas, Power and change: explaining EU-Russia energy relations', Journal of European Public Policy 21/1(2014) p.59.

${ }^{8}$ Ibid, p.63.

${ }^{9}$ Ibid, pp.58-75. 
${ }^{10}$ G. Bridge, 'Energy (in)security: world-making in an age of scarcity', The Geographical Journal (2014) pp.328-339.

${ }^{11}$ E. Kirchner and C. Berk, 'European energy security co-operation, p. between amity and enmity', Journal of Common Market Studies 48(2010) p.872.

${ }^{12}$ S. Bouzarovski and M. Bassin, 'Energy and Identity: Imagining Russia as a Hydrocarbon Superpower', Annals of the Association of American Geographers 101/4(2011) p.787.

${ }^{13}$ G. Bosse, 'The EU's Geopolitical Vision of a European Energy Space: When 'Gulliver' meets 'White Elephants' and Verdi Babylonian King', Geopolitics 16/3 (2011) p.529.

${ }^{14}$ G. Bridge, 'Resource Geographies I: Making Carbon Economies, Old and New', Progress in Human Geography 35/6(2010) p.829.

${ }^{15}$ A. Bumpus and D. Liverman, 'Accumulation by Decarbonisation and the Governance of Carbon Offsets', Economic Geography 84/2 (2008) p.131.

${ }^{16}$ T. Romanova, 'Is Russian Energy Policy towards the EU only about Geopolitics? The Case of Third Liberalisation Package', Geopolitics (2016) p.15.

17 Bouzarovski and Bassin (note 12); P. Rutland, 'Russia as an energy superpower', New Political Economy, 13/2(2008) pp.203-10.

${ }^{18}$ T. Romanova (note 16)p.15; E. Kropatcheva, 'Playing Both Ends against the Middle: Russia's Geopolitical Energy Games with the EU and Ukraine', Geopolitics 16/3 (2011), p.554; E. Butler, 'The Geopolitics of Merger and Acquisition in the Central European Energy Market', Geopolitics 16/3(2011) p.628.

${ }^{19}$ Interview \#10.

${ }^{20}$ F. Umbach, 'Global Energy Security and the implications for the EU', Energy Policy 38/3 (2010) p.1231

${ }^{21}$ M. Gurses, 'State-sponsored development, Oil and Democratisation', Democratization 16/3 (2009), p. 508; M. Watts, 'Resource curse? Governmentality, Oil, and Power in the Niger

Delta, Nigeria', Geopolitics 9/1 (2004) p.54.

${ }^{22}$ Bouzarovski and Bassin (note 12) p.790.

${ }^{23}$ Russian Government, 'Энергетическая стратегия России на период до 2030 года', (Energy Strategy of the Russian Federation for the Period up to 2030), (2009) p.5, http://www.infobio.ru/sites/default/files/Energostrategiya-2030.pdf,

${ }^{24}$ P. Aalto, D. Dusseault, M. D. Kennedy, M.Kivinen, 'Russia's Energy Relations in the East and West: Towards a Social Structurationist Approach to Energy Policy Formation', Journal of International Relations and Development 17/1(2014) p.24.

${ }^{25}$ R. Sakwa, 'Looking for a greater Europe: From mutual dependence to an international regime', Communist and Post-Communist Studies 45/3-4) (2012), pp.315-325; C. Nitoiu, EU-Russia relations: Between conflict and Cooperation, International Politics 51(2014) pp.234-253.

${ }^{26}$ M. Light, 'Keynote Article: Russia and the EU: Strategic Partners or Strategic Rivals?' Journal of Common Market Studies 46/annual review (2008) pp.18; 25-26.

${ }^{27}$ B. Buzan, From International to World Society? (Cambridge: CUP 2004) p.152.

${ }^{28}$ R. Grajauskas and L. Kasciunas, 'Modern versus Postmodern Actor of International Relations: Explaining EU-Russia Negotiations on the New Partnership Agreement', Lithuanian Foreign Policy Review 22(2009) p.80; K. Barysch, 'The EU and Russia: From Principle to Pragmatism', Centre for European Reform Policy, (2006), www.cer.org.uk/pdf/EU_russia_barysch_final_10nov06.pdf

${ }^{29}$ Klinke characterised it as a modern-postmodern binary: a " "modern' framework of fixed territory, national identity and traditional geopolitics, the European Union is driven by a 
'postmodern' spatial mindset that transcends these 'backward' values" see I. Klinke, 'Postmodern Geopolitics? The European Union Eyes Russia', Europe-Asia Studies 64/5 (2012) p.9. Also, H. Haukkala, 'The EU-Russia Strategic Partnership: The Limits of Post-Sovereignty in International Relations', (2010) London: Routledge; H. Haukkala, 'From Cooperative to Contested Europe? The Conflict in Ukraine as a Culmination of a Long-Term Crisis in EURussia Relations', Journal of Contemporary European Studies 23/1(2015) pp.25-40.

${ }^{30}$ O. Rehn, 'Europe's Smart Power in the Region and the World', Speech - EU Commissioner for Enlargement, (1 May 2008), http://wwwold.sant.ox.ac.uk/seesox/pdf/rehn_speech2008.pdf

${ }^{31}$ Umbach (note 20) p.1233.

${ }^{32}$ D. Finon and C. Locatelli, 'Russian and European Gas Interdependence: Could Contractual Trade Channel Geopolitics?', Energy Policy 36/1(2008) p.426.

${ }^{33}$ Kuzemko (note 7); R. Youngs, Energy Security: Europe's New Foreign Policy Challenge, (London: Routledge 2009); Haukkala (note 29).

${ }^{34}$ R. Leal-Arcas, 'The EU and Russia as Energy Trading Partners: Friends or Foes?', European Foreign Affairs Review 14/3(2009) pp.337-366.

${ }^{35}$ P.O. Eikeland, 'The Third Internal Energy Market Package: New Power Relations among Member States, EU Institutions and Non-state Actors?', Journal of Common Market Studies 49/2(2011), pp.243-263.

${ }^{36}$ I. Manners, 'Normative Power Europe: A Contradiction in Terms?', Journal of Common Market Studies 40/2(2002) p.239.

${ }^{37}$ S. Lavrov, 'State of the union Russia-EU: Prospects for partnership in the changing world', Journal of Common Market Studies 51/S1(2013) pp.6-12.

${ }^{38}$ P. Aalto, 'The EU-Russia Energy Dialogue and the Future of European Integration: From Economic to Politico - Normative Narratives, in P. Aalto (ed.) The EU-Russian Energy Dialogue: Europe's Future Energy Security, (Farnham: Ashgate 2008) pp.23-42; O. Khrushcheva, 'The creation of an Energy Security Society as the way to decrease securitization levels between the EU and Russia in energy trade', Journal of Contemporary European

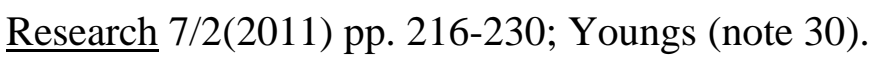

${ }^{39}$ Gazprom often uses oil indexed gas prices on long-term contracts, particularly in Central and Eastern Europe. Since the financial crisis of 2008 oil-indexed gas prices have been substantially higher than non oil-indexed, spot prices.

${ }^{40}$ A. Dhaka, 'The Geopolitics of Energy Security and the Response to its Challenges by India and Germany', Geopolitics 14/2(2009) p.279.

${ }^{41}$ Klinke (note 29) p.929.

42 J. Gower and G. Timmins, 'Introduction: The European Union, Russia and the Shared Neighbourhood', Europe-Asia Studies, 61/10(2009), p.1686; see also A. Herranz-Surrallés, 'An emerging EU energy diplomacy? Discursive shifts, enduring practices', Journal of European Public Policy (2015); Umbach (note 17).

${ }^{43}$ Kuzemko (note 7) p.67.

${ }^{44}$ Kuzemko (note 7) p.65.

45 A. Goldthau and N. Sitter, 'A liberal actor in a realist world? The Commission and the external dimension of the single market for energy', Journal of European Public Policy 21/10(2014) p.1468. 
${ }^{46}$ A. Schmidt-Felzmann, 'All for One? EU Member States and the Union's Common Policy Towards the Russian Federation', Journal of Contemporary European Studies 16/2(2008) 169187; C. Carta and S. Braghiroli, 'Measuring Russia's snag on the fabric of the EU's international society: The impact of the East-West cleavage upon the Cohesion amongst the EU Member States vis-à-vis Russia', Journal of Contemporary European Research 7/2(2011) pp.260-290.

${ }^{47}$ Herranz-Surrallés (note 42); T. Maltby, 'Between amity, enmity and Europeanisation: EU Energy security policy and the example of Bulgaria's Russian energy dependence', EuropeAsia Studies 67/5(2015) pp.809-830.

${ }^{48}$ Kuzemko (note 7) p.58.

${ }^{49}$ EU/RF Roadmap (note 1).

${ }^{50} \mathrm{P}$. Aalto and D. K. Temel, 'European energy security: natural gas and the integration process', Journal of Common Market Studies 52/4(2014) p.766.

${ }^{51}$ EU/RF Roadmap (note 1).

${ }^{52}$ P. Aalto, 'The Emerging New Energy Agenda and Russia: Implications for Russia's Role as a Major Supplier to the EU', Acta Slavica Iaponica 30(2011) p.11.

${ }^{53}$ EU/RF Roadmap (note 1) p.18.

${ }^{54}$ EU/RF Roadmap (note 1) pp.25; 21; 22.

${ }^{55}$ International Energy Agency, 'Russia 2014' (2014) p.45, https://www.iea.org/publications/freepublications/publication/Russia_2014.pdf ${ }^{56}$ Aalto and Temel (note 50) p.762.

${ }^{57}$ D. Toke and S.-E. Vezirgiannidou, 'The relationship between climate change and energy security: key issues and conclusions', Environmental Politics 22/4(2013) p.546; Interview \# 1. ${ }^{58}$ EU/RF Roadmap (note 1) p.22.

${ }^{59}$ Bouzarovski and Bassin (note 12) p.787.

${ }^{60} \mathrm{~J}$. Checkel, 'A constructivist research programme in EU studies' European Union Politics 2/2(2001) pp.219-249.

61 J. G. Ruggie, 'What Makes the World Hang Together? Neo-utilitarianism and the Social Constructivist Challenge', International Organization 52/04(1998) pp.855-885.

${ }^{62}$ I.B. Neumann, 'Returning practice to the linguistic turn: the case of diplomacy', Millennium: Journal of International Studies 31/3(2002) p.641.

${ }^{63}$ P. Hall, 'Policy Paradigms, Social Learning and the State: The Case of Economic PolicyMaking in Britain', Comparative Politics 25/3(1993) p.287.

${ }^{64}$ Kuzemko (note 7) p.63.

${ }^{65}$ F. Ciuta, 'Security and the Problem of Context: A Hermeneutical Critique of Securitization Theory', Review of International Studies, 35/2(2009) p.320.

${ }^{66}$ Klinke (note 29) p.943.

${ }^{67}$ Herranz-Surrallés (note 42) p.7.

${ }^{68}$ A. Jordan, H. van Asselt, F. Berkhout, D. Huitema, and D. Rayner, 'Understanding the Paradoxes of Multilevel Governing: Climate Change Policy in the European Union', Global Environmental Politics 12/2(2012) p.48.

${ }^{69}$ M. Schreurs and Y. Tiberghien, 'Multi-level Reinforcement: Explaining European Union Leadership in Climate Change Mitigation', Global Environmental Politics 7/4(2007) p.22.

${ }^{70}$ Jordan et al (note 68) pp.44-45. 
${ }^{71}$ S. Oberthür, 'The European Union's Performance in the International Climate Change Regime', Journal of European Integration 33/6(2011) p.676.

${ }^{72}$ T. Blair, 'Press conference at EU informal summit Hampton Court', (27 October 2005) http://www.le.ac.uk/eg/hvdc/Link\%20pages/News\%20Items/Press\%20conference_PM_\%20 Hampton\%20Court.doc

${ }^{54}$. European Commission, 'Guidance on the use of Renewable Energy Cooperation Mechanism', SWD(2013) 440 final, (5 Nov 2013) p.131. http://ec.europa.eu/energy/gas_electricity/doc/com_2013_public_intervention_swd05_en.pdf 55. European Commission, '2030 Framework for Climate and Energy Policies', (24 October 2014), http://ec.europa.eu/clima/policies/2030/index_en.htm.

${ }^{75}$ European Commission, 'Communication on Energy Efficiency', (2014) http://ec.europa.eu/energy/efficiency/events/doc/2014_eec_communication_adopted.pdf ${ }^{76}$ European Commission, '2030 climate and energy goals for a competitive, secure and lowcarbon EU economy', (22 Jan 2014) http://europa.eu/rapid/press-release_IP-14-54_en.htm .

${ }^{77}$ Interview \#2.

${ }^{78}$ Interview \#3; also interview \#4.

${ }^{79}$ Interview \#3.

${ }^{80}$ European Commission (note 6) p.3.

${ }^{81}$ European Council, 'A secure Europe in a better world - The European Security Strategy', (12 December 2003), https://www.consilium.europa.eu/uedocs/cmsUpload/78367.pdf;

European Council, 'Report on the Implementation of the European Security Strategy', (11 December 2008), https://www.satcen.europa.eu/\#.

${ }^{82}$ European Commission, 'Communication from the Commission to the European Parliament, the Council, the European Economic and Social Committee and the Committee of the Regions: A Roadmap for moving to a competitive low carbon economy in 2050', COM (2011) 112, p. 5, http://eur-lex.europa.eu/legalcontent/EN/TXT/PDF/?uri=CELEX:52011DC0112\&from=EN

${ }^{83}$ European Commission, Coal and other solid fuels, https://ec.europa.eu/energy/en/topics/oil-gas-and-coal/coal-and-other-solid-fuels

${ }^{84}$ European Commission, 'Structural reform of the European carbon market' (April 2016), http://ec.europa.eu/clima/policies/ets/reform/index_en.htm

${ }^{85}$ The European Parliament and the Council, 'Directive 2010/75/EU of the European Parliament and of the Council of 24 November 2010 on industrial emissions (integrated pollution prevention and control)', (2010), http://eurlex.europa.eu/LexUriServ/LexUriServ.do?uri=OJ:L:2010:334:0017:0119:en:PDF

${ }^{86}$ Oberthür (note 71) pp.675-676.

${ }^{87}$ Jordan et al (note 68) p.59.

${ }^{88}$ S. Baker, 'Sustainable development as Symbolic Commitment: Declaratory Politics and the Seductive Appeal of Ecological Modernisation in the European Union' Environmental

Politics 16/2(2007) pp.297-317, p.313.

${ }^{89}$ Baker (note 88) p.312.

${ }^{90}$ Manners (note 36).

91 Toke and Vezirgiannidou (note 57) p.547.

${ }^{92}$ J. Skovgaard, 'EU climate policy after the crisis', Environmental Politics 23/1(2014) p.6.

93 Interview \#5.

${ }^{94}$ Kuzemko (note 7) pp.59-60. 
${ }^{95}$ M. Braun, 'EU Climate Norms in East-Central Europe', Journal of Common Market Studies 52(2014) p. 457; Oberthür (note 57) p.676; M. Bradshaw, 'Global Energy Dilemmas: A Geographical Perspective', The Geographical Journal 176/4(2010) p.285.

${ }^{96}$ D. Buchan, Energy and Climate Change: Europe at the Crossroads, (Oxford: OUP 2009).

${ }^{97}$ J. Skovgaard, 'The Limits of Entrapment: The Negotiations on EU Reduction Targets, 2007-11', Journal of Common Market Studies 51(2013) p.1154.

${ }^{98}$ Skovgaard (note 90) pp.9-10.

${ }^{99}$ European Commission, '2030 framework for climate and energy policies', (24 October 2014), http://ec.europa.eu/clima/policies/2030/index_en.htm.

${ }^{100}$ C. Wagnsson, 'Divided power Europe: normative divergences among the EU 'big three', Journal of European Public Policy 17/8(2010) pp.1089-1105.

${ }^{101}$ European Commission, 'Report from the Commission to the European Parliament, the Council and Social Committee and the Committee of the Regions, Renewable energy progress report', COM (2015) 293 final, (2015) pp.4-5. ${ }^{102}$ European Parliament and the Council, 'Directive 2009/28/EC of the European Parliament and of the Council of 23 April 2009 on the promotion of the use of energy from renewable sources', (2009) p. 20, http://eur-lex.europa.eu/legalcontent/EN/TXT/PDF/?uri=CELEX:32009L0028\&from=EN ${ }^{103}$ European Parliament and the Council (note 102) p.20.

${ }^{104}$ Euractiv 'Desertec abandons Sahara solar export dream', (31 May 2013), http://www.euractiv.com/energy/desertec-abandons-sahara-solar-p-news-528151 105 A. Boute and P. Willems, 'Greening Europe's energy supply by developing Russia's renewable energy potential', Energy Policy 51(2012) pp.618-629.

106 European Commission, 'Europeans attitude towards climate change', Special Eurobarometer 300(2008), http://ec.europa.eu/public_opinion/archives/ebs/ebs_300_full_en.pdf.

107 European Commission, 'Climate Change', Special Eurobarometer 435(2015), http://ec.europa.eu/clima/citizens/support/docs/report_2015_en.pdf.

108 J. Vogler, 'Changing conceptions of climate and energy security in Europe', Environmental Politics 22/4(2013) pp.639-640.

109 A. Piebalgs, 'EU energy and climate policy: speech at the 7th Doha Natural Gas Conference', (11 Mar 2009), http://europa.eu/rapid/press-release_SPEECH-09102_en.htm?locale=en.

${ }^{110}$ C. Hedegaard, European Commissioner for Climate Action cited in Harvey, F. 'EU agrees to improve energy efficiency $30 \%$ by 2030 ', The Guardian, (23 July 2014 ), http://ec.europa.eu/energy/doc/20140528_energy_security_study.pdf ${ }^{111}$ Oberthür (note 71); also European Commission, "Reasons to be hopeful", (28 November) 2008, http://europa.eu/rapid/press-release_SPEECH-08-661_en.htm

112 E. Nikitina, 'Russia: Climate Policy Formation and Implementation during the 1990s', Climate Policy 1(2001) p.299.

${ }^{113}$ Ibid, p.293.

114 Russian Government, ‘Энергетическая стратегия России на период до 2020’ (Energy Strategy of Russia for the Period up to 2020), (2003)http://www.cpnt.ru/userfiles/_files_normativ_energosafe_energostrategy.pdf 
115 A. Brown, 'Russian Renewable Energy Market: Design and Implementation of National Policy', Russian/CIS Energy and Mining Law Journal 3(2006) p.34.

${ }^{116}$ Russian Government, 'Комплексный план действий по реализации в Российской Федерации Киотского протокола к рамочной Конвенции ООН об изменении климата' (the National Action Plan on Kyoto Protocol Implementation), (2005), http://economy.gov.ru/minec/activity/sections/nature/kioto/doc1116233267875

117 Russian Government 'Постановление Правительства от 3 июня 2008 г. №426 О квалификации генерирующего объекта, функционирующего на основе использования возобновляемых источников энергии', (Decree of the Government of the Russian Federation “On the Qualification of Renewable Energy Generating Installations" No. 426) June 3rd 2008, http://www.bellona.ru/Casefiles/pravit_426.

118 Russian Government (note 23).

${ }^{119}$ Russian Government (note 23) p.74.

${ }^{120}$ Russian Government, 'Распоряжение Правительства Российской Федерации от 8 января 2009 г. № 1-р “О государственной политике в сфере повышения энергоэффективности и развития возобновляемой энергетики" (Decree of the Government of the Russian Federation "On Main Directions of the Governmental Policy on Increasing of Energy Efficiency in Electricity Sector based on Renewable Energy Sources for the Period until 2020" No. 1-r) (8 January 2009),

http://www.infobio.ru/sites/default/files/Pravitelstvo_Rossiyskoy_Federacii.pdf

${ }^{121}$ M. Garbuzova and R. Madlener, 'Towards an efficient and low carbon economy post2012: opportunities and barriers for foreign companies in the Russian energy market', Mitigation and Adaptation Strategies for Global Change 17(2011) p.395.

122 Interview \#7.

${ }^{123}$ Interview \#6.

${ }^{124}$ IFC, 'Renewable Energy Policy in Russia: Waking the Green Giant', (2011) p.10, http://www.ifc.org/wps/wcm/connect/bf9fff0049718eba8bcaaf849537832d/PublicationRussia RREP-CreenGiant-2011-11.pdf?MOD=AJPERES

${ }^{125}$ Russian Government (note 23) p.74.

${ }^{126}$ Eurostat (2015) http://ec.europa.eu/eurostat/statistics-

explained/index.php/File:Overall_share_of_energy_from_renewable_sources_-_2013.png

${ }^{127}$ European Parliament and Council, 'Directive 2001/77/EC of the European Parliament and of the Council of 27 September 2001 on the promotion of electricity produced from renewable energy sources in the internal electricity market', (2001), http://eurlex.europa.eu/legal-content/EN/TXT/PDF/?uri=CELEX:32001L0077\&from=EN

${ }_{128}$ Russian Government, 'Комплексный план реализации Климатической доктрины Российской Федерации на период до 2020 года', (Comprehensive plan of implementing the Russian Federation's Climate Doctrine for the Period until 2020), (2011), http://bellona.ru/filearchive/fil_fil_National_Plan_Climate_Doctrine_2011.pdf

${ }^{129}$ Interview \#11.

${ }^{130}$ Russian Government, 'Проект Энергетической Стратегии на период до 2035' (Draft of Energy Strategy up to 2035), (2014) p.173, http://minenergo.gov.ru/upload/iblock/621/621d81f0fb5a11919f912bfafb3248d6.pdf,

${ }^{131}$ Ibid, p.175.

${ }^{132}$ Russian Government (note 23) p.175.

${ }^{133}$ Interview \#11. 
${ }^{134}$ B. Lukutin, 'Перспективы малой энергетики в Томской Области’ (Prospects for development of alternative energy in the Tomsk Region), http://www.rosteplo.ru/Tech_stat/stat_shablon.php?id=250

${ }_{135}$ Republic of Yakutiya, 'О Возобновляемых Источниках Энергии Республики Якутия' (On Renewable Energy Sources of the Republic of Yakutiya) (2014), http://www.sakha.gov.ru/special/sites/default/files/story/files/2014_03/11/\%203акона\%20B ИЭ.docx

${ }^{136}$ Aalto (note 52) p.1.

137 Interview \#13.

${ }^{138}$ L. Shafer, “ЭЭергия вращения”: как и чем живёт ветропарк в посёлке Куликово, (Energy of rotation: what is going with the windfarm in Kulikovo?), (2013), http://kgd.ru/news/society/item/30068-jenergiya-vrashheniya-kak-i-chem-zhivjot-vetroparkv-posjolke-kulikovo.

${ }^{139} \mathrm{~S}$. Lomakin, 'Деньги на ветер. Почему альтернативная энергетика не приносит дохода?' (Wasted money: Why you cannot make any profit from alternative energy?), Argumenty I Fakty 35, (2014), http://www.klg.aif.ru/society/1326159.

${ }^{140}$ Russian Government, 'Постановление Правительства N 47 от 23 января 2015 O внесении изменений в некоторые акты Правительства Российской Федерации по вопросам стимулирования использования бозобновляемных источников энергии на розничных рынках электрической энергии' (Governmental Decree N47 On Amendments to Certain Acts of the Russian Federation on renewable energy on the electricity markets) http://government.ru/media/files/WATItEFgK8c.pdf,

${ }^{141}$ Interview \#11.

142 Corporation Development, 'Обзор развития отрасли альтернативной энергетики в 2014 году, Спецвыпуск, Корпорация Развития Белгородская Область’, (Development Review of the alternative energy in 2014), (2014) p.25, http://belgorodinvest.com/files/alt\%20energy.pdf.

143 Interview \#11.

144 Interview \#11.

${ }^{145}$ Russian Government, 'Постановление Правительства РФ от 28.05.2013 N 449 (ред. от 17.02.2014) "О механизме стимулирования использования возобновляемых источников энергии на оптовом рынке электрической энергии и мощности"', (Governmental Decree No 449 Mechanism for the Promotion of Renewable Energy), (2014) p. 7 ,

http://base.consultant.ru/cons/cgi/online.cgi?req=doc;base=LAW; $=159297 ; \mathrm{fld}=134 ; \mathrm{dst}=100$ 0000001,$0 ; \mathrm{rnd}=0.10319439764134586$

146 Ibid.

${ }^{147}$ Interview \#13.

${ }^{148}$ P. Rutland, 'The Impact of Sanctions on Russia', Russian Analytical Digest, 157(2014), pp.2-8, http://www.laender-analysen.de/russland/rad/pdf/Russian_Analytical_Digest_157.pdf 149 Interview \#13.

${ }^{150}$ I. Overland and H. Kjaernet, Russian Renewable Energy: The Potential for International Cooperation, (Farnham: Ashgate 2009) p.6.

${ }^{151}$ Russian Government (note 114) p.18.

152 Russian Government, 'Климатическая Доктрина Российской Федерации', (Climate

Doctrine of the Russian Federation), (2009) p.10.

https://www.mnr.gov.ru/files/part/9500_project_doctrine.doc.

${ }^{153}$ Russian Government (note 23).

${ }^{154}$ Ibid pp. 4,9,73.

155 Russian Government 'Прогноз Долгосрочного Социально-экономического развития Российской Федерации на период до 2030 года' (Projection of long-term social and 
economic development of the Russian Federation until 2030), (2013), p. 159, http://economy.gov.ru/minec/activity/sections/macro/prognoz/doc20130325_06

${ }^{156}$ Perm Municipal Programme, 'Проект Муниципальной Программы Энергосбережение и Повышение Энергетической Эффективности города Перми на период до 2011-2015 $г \Gamma^{\prime}$ (Perm Municipal Programme on Improving Energy Efficiency in 2011-2015), (2011), http://www.gorodperm.ru/upload/pages/9542/Municipalnaja_Programma_EPE_Permi_19.02. 11.doc

${ }^{157}$ United Nations Environment Programme JI Projects Pipeline, (1 April 2016), http://cdmpipeline.org/publications/JiPipeline.xlsx

${ }^{158}$ Russian Government (note 23).

${ }^{159}$ Rosenergo, 'Перечень основных нормативных правовых актов Российской Федерации в области энергосбережения и повышения энергетической эффективности', (List of the major legal and regulatory acts on energy saving and energy efficiency), (2015), http://rosenergo.gov.ru/regulations_and_methodologies/normativnie_akti_v_oblasti_energosb erezheniya

${ }^{160}$ Russian Government, 'Кодекс Российской Федерации об административных правонарушениях', (The code of administrative offences of the Russian federation of 30.12.2001 (ed. 05.10.2015), Article 9.16, http://www.consultant.ru/popular/koap/ 161 Interview \#11,

162 Russian Government, 'Государственная программа Российской Федерации 'Энергосбережение и повышение энергетической эффективности на период до 2020 года', (State National Programme of the Russian Federation on Energy Savings and Improvement of Energy Efficiency until 2020), (2010), Article 9.16

http://www.infobio.ru/sites/default/files/2446.pdf

163 Ibid p.9.

${ }^{164}$ Interview \# 11; I. Bashmakov and A. Myshak, 'Russian energy efficiency accounting system', Energy Efficiency 7/5 (2014) p.747.

${ }^{165}$ Russian Government, 'Основные направления бюджетной политики на 2015 год и на плановый период 2016 и 2017 годов’, (Main directions of the budget policy in 2015, and for the planned period in 2016 and 2017), (2015)

http://budget.gov.ru/epbs/content/conn/content/path/Contribution\%20folders/documents/Osn ovnie_napravleniya_budgetnoi_politiki.pdf,

${ }^{166}$ Interview \#7; Interview \#10; Interview \#11.

${ }^{167}$ V. Putin 'Meeting with participants in the CEO Global Summit', (May 2014), http://eng.kremlin.ru/news/7228

${ }^{168}$ L. A. Henry and L. M. Sundstrom, 'Russia's Climate Policy: International Bargaining and Domestic Modernisation', Europe-Asia Studies 64/7(2012) pp.1297-1322.

${ }^{169}$ L. Andonova and A. Alexieva, 'Continuity and change in Russia's climate negotiations position and strategy', Climate Policy 12/5(2012) pp.614-629.

${ }^{170}$ Russian Government (note 152).

${ }^{171}$ Henry and Sundstrom (note 168) pp.1299-1301.

172 D. Medvedev, 'Go, Russia!', (Sept. 2009), http://archive.kremlin.ru/eng/speeches/2009/09/10/1534 type104017_221527.shtml

${ }^{173}$ Russian Government, 'Opening Remarks at Security Council Meeting on Climate Change', (2010), http://archive.kremlin.ru/eng/speeches/2010/03/17/1931_type82913_224806.shtml ${ }^{174}$ A. Korppoo, 'Who is driving Russian climate policy? Applying and adjusting veto players theory to a non-democracy', International Environmental Agreements: Politics, Law and Economics (2015) 115, p. 4-7; A. Turkowski, 'Russia's international climate policy', The 
Polish Institute of International Affairs (April 2012) p.2, http://www.isn.ethz.ch/DigitalLibrary/Publications/Detail/?lang=en\&id=141973

${ }^{175}$ Putin in 2013 at the G20 St Petersburg Summit, 'it is essential to encourage the green growth and support the world community's efforts to prevent climate change' (6 September 2013), http://en.kremlin.ru/events/president/news/19168.

176 Turkowski (note 174) p.2.

${ }^{177}$ M. Poberezhskaya, 'Media Coverage of Climate Change in Russia: Governmental Bias and Climate Science', Public Understanding of Science (2014) p.5.

${ }^{178}$ Skovgaard (note 92) p.6.

${ }^{179}$ Henry and Sundstrom (note 168) p.1308.

${ }^{180}$ A. Kokorin and A. Korppoo, 'Russia's Post-Kyoto Climate Policy: Real Action or Merely Window-Dressing?' FNI Policy Perspectives 10 (2013) p.2, http://www.fni.no/doc\&pdf/FNI-Climate-Policy-Perspectives-10.pdf

${ }_{181}$ O. Dobrovidova, 'Ahead of Paris, Russia becomes a climate policy wallflower', Climate Change News (29 July 2015), http://www.climatechangenews.com/2015/07/29/ahead-ofparis-russia-becomes-a-climate-policy-wallflower/

182 Russian Government, 'Указ Президента Российской Федерации от 30 сентября 2013 г. N 752', (Presidential Decree N752) (Sept. 2013), http://www.rg.ru/2013/10/04/eco-dok.html ${ }^{183}$ INDC, Russian Federation, (2015), http://www4.unfccc.int/submissions/indc/Submission\%20Pages/submissions.aspx

${ }^{184}$ Russian Government, 'План мероприятий по обеспечению к 2020 году сокращения объема выбросов парниковых газов до уровня не более 75 процентов объема указанных выбросов в 1990 году', (The Action Plan on the reduction of greenhouse gas emission volumes) (2014) http://cdnimg.rg.ru/pril/95/43/83/504_plan.pdf ${ }^{185}$ Interview \#11.

${ }^{186}$ A. Korppoo, N. Tynkkynen, G Honneland, Russia and the Politics of International Environmental Regimes, (Cheltenham: Edward Elgar 2015) p.141.

${ }^{187}$ Ibid, p.47.

188 WCIOM, 'Спасти Планету или кошелек: для чего мы экономим электроэнергию?'(Environmental situation in Russia: worse from year to year), Press release No.1548 (29 July 2010), http://wciom.ru/index.php?id=459\&uid=13708

189 WCIOM, 'Спасти Планету или кошелек: для чего мы экономим электроэнергию?' (To save the planet or to save your wallet: why are we trying to save energy?), N2334, (2013), http://wciom.ru/index.php?id=459\&uid=114261

${ }^{190}$ Poberezhskaya (note 177) p.12.

${ }^{191}$ M. Boykoff, 'Flogging a dead norm? Newspaper coverage of anthropogenic climate change in the United States and United Kingdom from 2003 to 2006', Area 39(2007) p.479. 192 A. Smith and F. Kern, 'The transitions storyline in Dutch environmental policy', Environmental Politics 18/1 (2009) p.96; S. Jiusto, 'Energy transformations and geographic research' in N. Castree, D. Demeritt, D. Liverman, and B. Rhoads (eds), A Companion to Environmental Geography, (Oxford: Blackwell 2009) p.535.

${ }^{193}$ Russian Government, 'Федеральный закон Российской Федерации от 23 ноября 2009 г. N 261-Ф3', (Federal Law No. 261-FZ “On energy saving and improvement of energy efficiency") (2009), Article 9, http://www.rg.ru/2009/11/27/energo-dok.html. ${ }^{194}$ Interview \#8.

${ }^{195}$ S. Boussena and C. Locatelli, 'Energy Institutional and Organisational changes in EU and Russia: Revisiting gas relations', Energy Policy 55(2013) p.186; A. Boute, 'Energy 
Efficiency as a New Paradigm of the European External Energy Policy: The Case of the EURussia Energy Dialogue', Europe-Asia Studies 65/6(2013) p.1036.

${ }^{196}$ Russian Government, 'Изменение цен (тарифов) на продукцию (услуги) компаний инфраструктурного сектора до 2017 года', (Predicted tariff changes for goods and services until 2017), (2014) http://economy.gov.ru/wps/wcm/connect/57551326-23f7-4fb7-9ba0064cb744c457/Condition+\%D1\%82\%D0\%B0\%D1\%80\%D0\%B8\%D1\%84\%D1\%8B.xls?M OD=AJPERES\&CACHEID=57551326-23f7-4fb7-9ba0-064cb744c457

${ }^{197}$ Russian Government (note 196).

198 Lenta, 'ФАС инициировала заморозку тарифив естественных монополий в 2016 году' (FAS proposed to freeze tariffs in 2016), (1 September 2015), http//:lenta.ru/news/2015/09/01/fas/ ${ }^{199}$ Garbuzova and Madlener (note 121) p.399.

${ }^{200}$ Andonova and Alexieva (note 169) p.618; Boussena and Locatelli (note 195) p.186.

${ }^{201}$ Interview \#9; M. Bilgin, 'Energy Security and Russia’s Gas Strategy: The Symbolic Relationship between the State and Firms', Communist and Post-Communist Studies 44(2011) p.122.

202 IFC, 'Energy Efficiency in Russia: Untapped Reserves', (2008) http://www.ifc.org/wps/wcm/connect/de1e58804aababd79797d79e0dc67fc6/IFC+EE+in+Ru ssia+Untapped+Potential.pdf?MOD=AJPERES

${ }^{203}$ S. Paltsev, 'Scenarios for Russia's natural gas exports to 2050', Energy Economics 42(2014) p.265.

${ }^{204}$ Russian Government (note 23) p.15.

${ }^{205}$ N. Smeets, 'Combating or Cultivating Climate Change? Russia's Approach to Renewable Energy as an Opportunity for the EU as a Facilitating actor', (Nov. 2014), https://lirias.kuleuven.be/bitstream/123456789/461009/2/smeets_n.pdf.

206 Interview \#7.

${ }^{207}$ Interview \#6.

${ }^{208}$ Boute (note 195); Kuzemko (note 7) p.49.

${ }^{209}$ EU/RF Roadmap (note 1) p. 22.

${ }^{210}$ Klinke (note 29); Goldthau and Sitter (note 45); Gower and Timmins (note 42); Kuzemko (note 7).

${ }^{211}$ Council 'Reinforced restrictive measures against Russia', ST 12944/14, PRESSE 460, (2014)

http://www.consilium.europa.eu/uedocs/cms_Data/docs/pressdata/EN/foraff/144868.pdf, 212 Interview \#9.

${ }^{213}$ Reuters, 'New blow for BP in Russia as office raided', (31 August 2011), http://www.reuters.com/article/us-bp-russia-raid-idUSTRE77U1EP20110831

${ }^{214}$ Interview \#12. 